\title{
Ventricular and Brain Stem Ependymal Tumor
}

National Cancer Institute

\section{Source}

National Cancer Institute. Ventricular and Brain Stem Ependymal Tumor. NCI Thesaurus.

Code $C 131578$.

An ependymal tumor affecting a brain ventricle and the brain stem. 